\title{
International Symposium on Nonlinear Theory and its Applications
} (NOLTA 2007, 非線形理論とその応用国際シンポジウム, http://nolta07.is.tokushima-u.ac.jp/)

Simon Fraser University at Harbour Centre, Vancouver, Canada 2007年9月 16日〜 19日

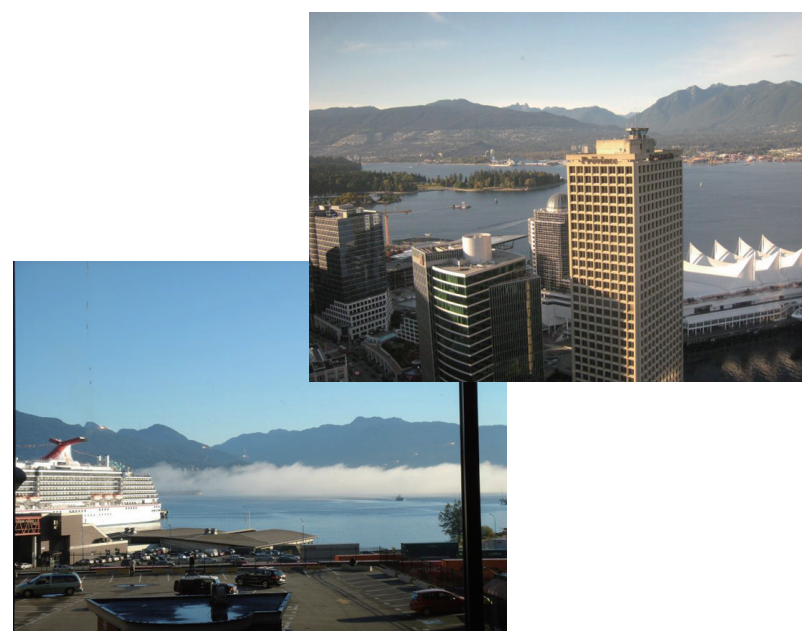

NOLTAシンポジウムは, 基礎·境界ソサイエティに属す る「非線形理論とその応用サブソサイエティ（通称 NOLTA サブソ)」のフラッグシップカンファレンスである．本会議 は，カオスや複雑系に代表される多様で複雑な非線形現象の 理解とそれらの工学的応用を目的として設立され，毎年，国 内外の都市で多数の参加者を集めて開催されている. 記念す べき 10 回目の海外開催となったNOLTA 2007は, サブ ソの前会長である本会フェローの奥村浩士教授（広島工業大 学教授・京都大学名誉教授) とIEEE CASSプレジデントの リリアナ・トライコビッチ教授 (サイモンフレーザー大学 · カナダ) がGeneral Co-Chairs となり, カナダのバンクー バーで開催された。青い空に, 青い海, 緑深い山々! 雄大な 大自然に囲まれたバンクーバーはまさに非線形現象を研究す る我々にとって最高の開催地となった。さらに会場は, 市内 中心部のハーバーセンター內にあるサイモンフレーザー大学 施設で，バンクーバ一のきれいな海と街を一望できた。 そん な最高の立地条件で行われたNOLTA2007, 会議内容もか なり充実したものとなった．全体講演では，アンソニー・ア

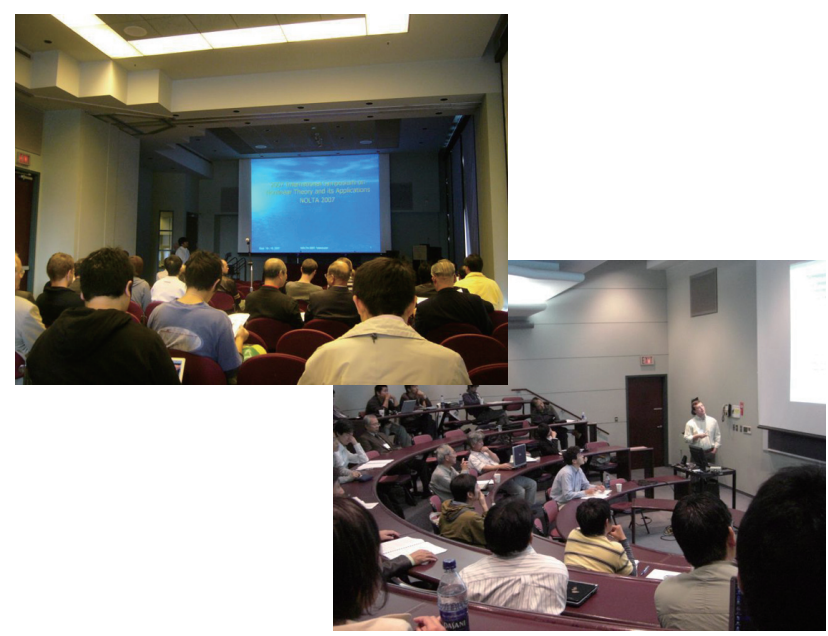

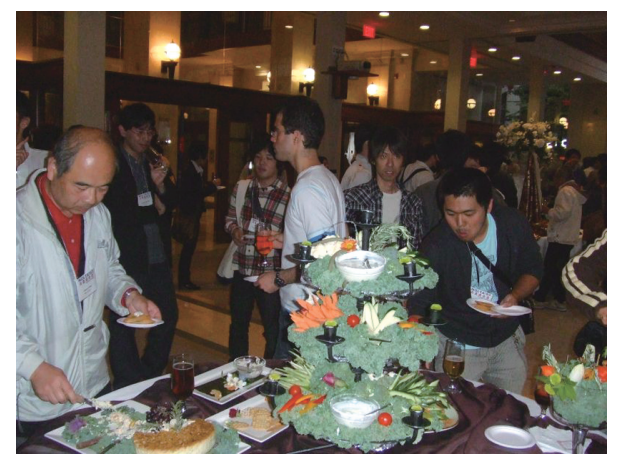

ロット教授 (サイモンフレーザー大学)による強磁性体の解析 についての招待講演と小川知之教授 (大阪大学) による時空 振動（尺八の演奏による実例紹介つきです!) についての招待 講演を聴講することができた. 論文総数は 140 件で, プロ グラムは 11 のスペシャルセッションと24のレギュラーセ シッョンの合計 35 セッションからなり, どのセッションで も活発なディスカッションが行われていた

会議のテクニカルプログラムもかなりのハイレベルであっ たが, ソーシャルイベントも引けを取らないぐらいの盛り上 がりを見せた. ウェルカムパーティは, 会議会場から少し 歩いたところにあるサイモンフレーザー大学のSFU Segal Graduate School of Businessで行われた. 八一バーセン

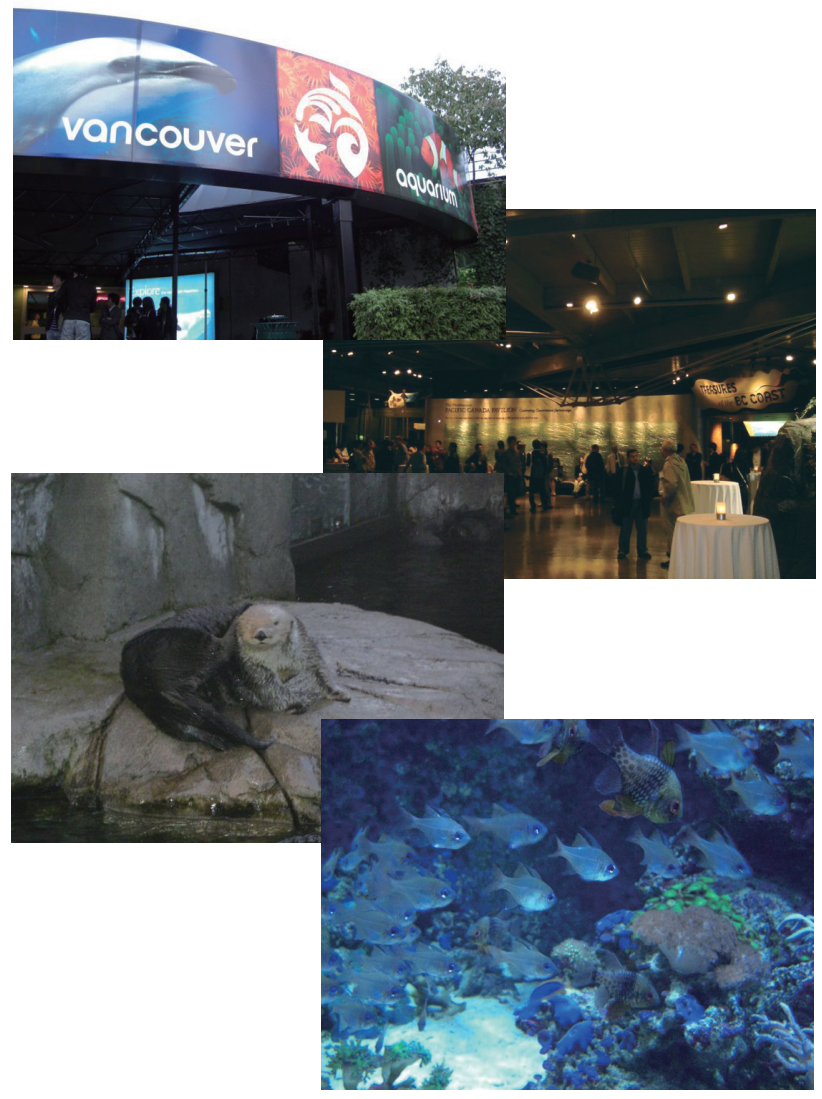


ターとは違い，歴史を感じさせる趣ある建物で，記念すべき 海外開催 10 回目のアニバーサリーにふさわしい会場であっ た. バンケットは, スタンレーパーク内にあるバンクーバー 水族館 (http://www.vanaqua.org/) を借り切って行われ た。 バンケット会場までは, 会議開場前から大型バスでの移 動であった．バスはスタンレーパーク内を2周してバンクー バ一水族館へ到着した（サービスか?道に迷っただけかはさ だかではないが・・・少，バンクーバー水族館はカナダで最 大の水族館であり，海洋研究や教育活動を目的とした非営利 組織である．巨大な水槽で泳ぐ魚の群れや屋外プールの愛ら しいラッコや珍しいベル一ガが魅力的であったことは言うま でもないが, パネルなどの教育的な展示物も非常に興味深く， 超複雑系である海洋生態系の世界を堪能することができた （たくさんの海洋生物の前で，シーフード料理をいただくの はちょつと心が痛かったが. ) 最終日のフェアウェルパーティ は，会議会場のプレナリ会場で行われた，参加者は有名ワイ
ンと美味しい料理を食しながら, 楽しい一時を過ごした. 次 回のNOLTAは, 2008年9月7〜10日にブダペスト(八 ンガリー)で開催の予定 (http://nolta2008.org/).

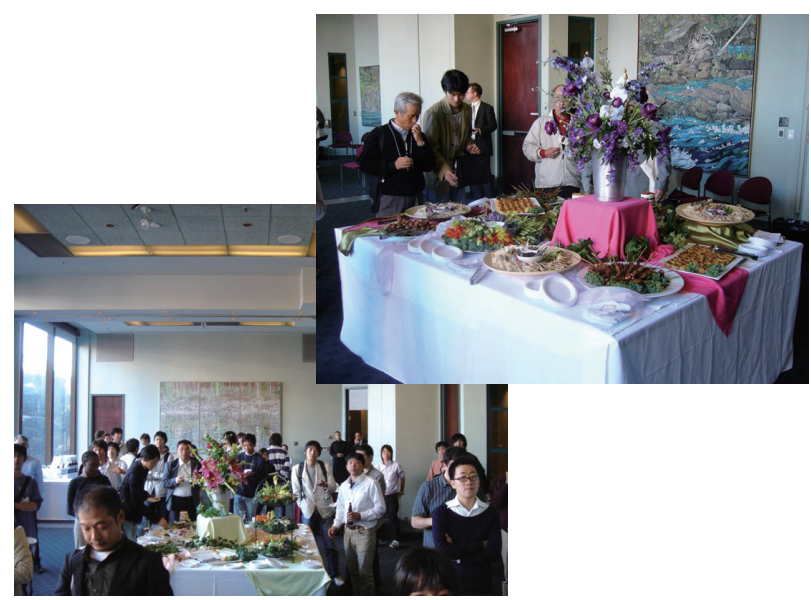

\section{NOLTA 2007 General Secretary からのバンクーバーお勧め情報!}

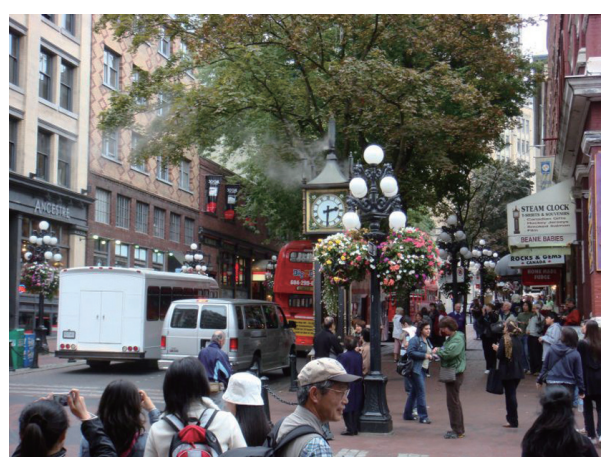

ギャスタウン：会議会場のすぐそばでした，通りの 両側にたくさんのおみやげ物屋さんが並んでいて, 財布が軽くなってしまいます。

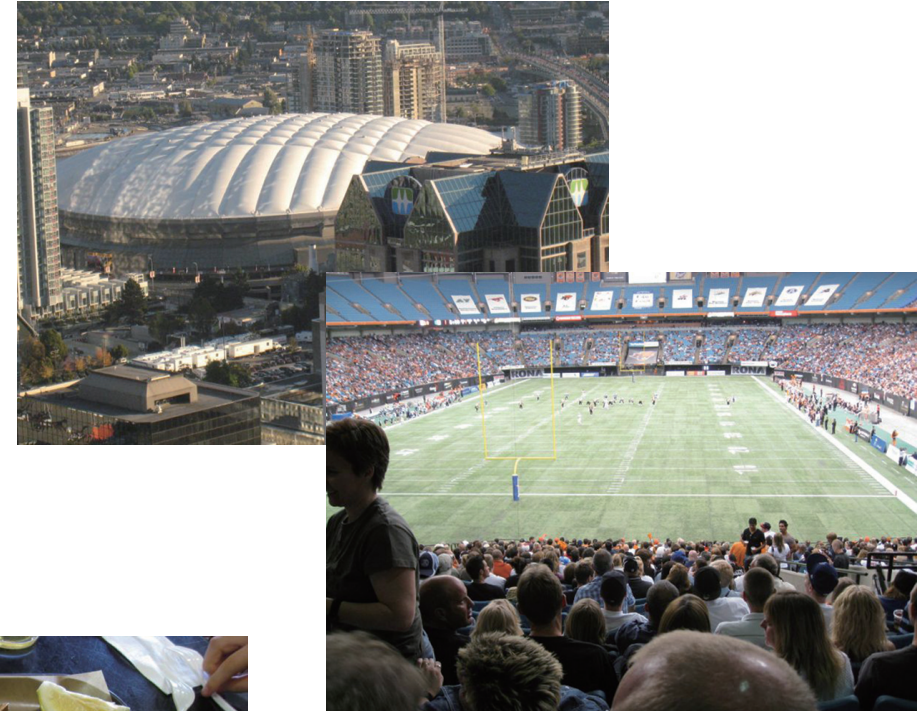

B.C.プレイス：カナディアンフットボールリーグ (CFL)のB.C. ライオンズの本拠地！NFLとは一味違 う攻守の交代が早いスリリングなフットボールを満 喫しよう!

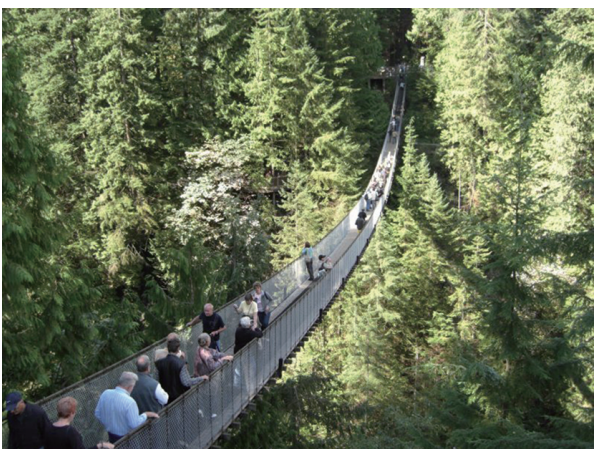

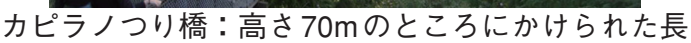
さ $173 \mathrm{~m}$ のつり橋. バンクーバーに来たら，このつ り橋は渡っておこう!けっこう摇れてスリリング 


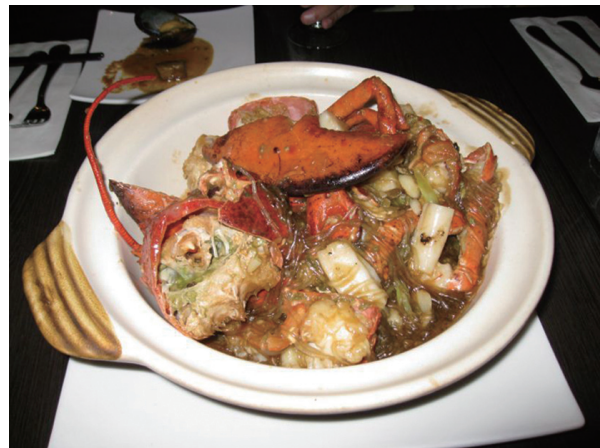

Prima Taste：バンクーバーは異文化が混じり合う国 際都市. シンガポール料理レストランPrima Taste のロブスター春雨惹 ( ? ) もはずせません!

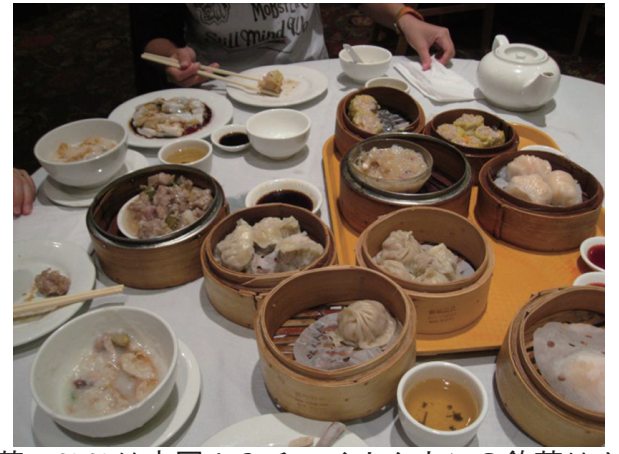

飲茶：ここは中国！?チャイナタウンの飲茶はやみ つきになること間違い無し!

\section{主催者へのインタビュー : NOLTA 2007 General Co-ChairのProf. Ljiljana Trajkovic (サイモンフレーザ大学・カ ナダ)にお聞きしました}

Q. 今回のNOLTAで特に良かったと思われた点はどこです か?

A. I very much enjoyed being part of the NOLTA organizing team and attending NOLTA 2007. It was, as always, very nice to see again my colleague and friends. However, above all, NOLTA was a unique opportunity to meet graduate students and share their feelings of enthusiasm and motivation when helping with local arrangements, attending daily to the registration desk and various duties at the symposium venue, and participating in the technical program and presenting their research papers. It was also very nice to enjoy with them NOLTA 2007 social events and the banquet at the Vancouver Aquarium.

Q. 今回のNOLTAの全体の感想をお聞かせ下さい.

A. NOLTA 2007 had smaller number of submitted papers and attendance than previous years. We attributed that to NDES held in July 2007 and ECCTD held in August 2007. All three meetings attract a similar group of researchers and many of them had to make a difficult choice which event to attend this summer. In spite of competing events, NOLTA 2007 was a great success, having approximately 200 attendees. The Technical Program was very well organized and included special sessions, work-in-progress sessions, and regular papers.

The symposium sessions and the welcome and farewell receptions were held at the Simon Fraser University Harbour Centre, conveniently located in the heart of downtown Vancouver. I found NOLTA 2007 to be a very fine symposium offering stimulating technical program and productive interactions with the participants. Even the Vancouver weather cooperated, offering sunshine and beautiful views to the symposium attendees. 